DOI: https://doi.org/10.24127/ajpm.v8i3.2259

\title{
PENGEMBANGAN LEMBAR KEGIATAN KALKULUS BERCIRIKAN REPRESENTASI MATEMATIS
}

\author{
Octavina Rizky Utami Putri ${ }^{1}$, Zukhrufurrohmah ${ }^{2}$ \\ ${ }^{1,2}$ Pendidikan Matematika, Universitas Muhammadiyah Malang \\ E-mail: $\quad$ octavina@umm.ac.id ${ }^{1)}$ \\ zukhrufurrohmah@umm.ac.id ${ }^{2)}$
}

Received 4 September 2019; Received in revised form 30 November 2019; Accepted 23 December 2019

\begin{abstract}
Abstrak
Penelitian ini bertujuan untuk menghasilkan Lembar Kegiatan Kalkulus bercirikan representasi matematis yang valid, praktis dan efektif. Prosedur penelitian terdiri dari penelitian pendahuluan, pembuatan prototipe, dan penilaian. Hasil validasi, observasi, kuesioner, dan tes dianalisis secara kuantitatif dan dijelaskan secara kualitatif. Penelitian ini telah menunjukkan bahwa Lembar Kegiatan Kalkulus yang ditandai dengan representasi matematis memenuhi kriteria valid, praktis dan efektif. Lembar Kegiatan Kalkulus bercirikan representasi matematis yang telah dikembangkan meliputi: pertanyaan terbimbing untuk menulis ringkasan sehingga memperoleh data representasi verbal, masalah matematika untuk memperoleh data representasi simbol, dan pertanyaan refleksi di akhir Lembar Kegiatan Kalkulus untuk mengukur representasi verbal dan simbolik.
\end{abstract}

Kata kunci: Lembar aktivitas kalkulus; pengembangan; representasi matematika.

\begin{abstract}
This study aimed to product Calculus Activity Sheets characterized by mathematical representations that are valid, practical and effective. The research method consisted of preliminary research, prototype making, and assessment. The results of the validation, observations, questionnaires, and tests were analyzed quantitatively and described qualitatively. This research has shown that Calculus Activity Sheets characterized by mathematical representations meet valid, practical and effective criteria. The Calculus Activity Sheets characterized by mathematical representation have been developed was include: guided questions to write summaries so that obtain verbal representation data, mathematical problems to obtain symbol representation data, and reflection questions at the end of Calculus Activity Sheets to measure students' verbal and symbolic representations.
\end{abstract}

Keywords: Calculus Activity Sheet; Development; Mathematical Representation.

\section{PENDAHULUAN}

Kalkulus merupakan salah satu matakuliah dasar yang penting dipelajari mahasiswa Teknik Sipil karena berkaitan dengan ilmu lain (Purnomo \& Faturohman, 2014). Kalkulus pada bidang Teknik Sipil, salah satunya diaplikasikan untuk merancang konstruk baja, mengukur tekanan fluida, dan lainnya. Oleh karena itu, kemampuan matematis perlu dikuasai oleh mahasiswa Teknik Sipil untuk dapat menyelesaikan masalah khususnya pada bidang Kalkulus. Salah satu kemampuan matematis yang memiliki peran penting dalam menginterpretasi kemampuan mahasiswa adalah representasi matematis.

Representasi merupakan bentuk interpretasi pemikiran, dapat berupa kata-kata verbal, tulisan, gambar, grafik atau simbol matematika, terhadap suatu masalah yang membantu menyelesaikan masalah tersebut (Astuti, 2017; Lestari \& Yudhanegara, 2017; Sabirin, 2014). Representasi dalam berbagai bentuk dan cara menunjukkan kegiatan berfikir 
matematis dan mengkomunikasikan ideide matematika seseorang (Hutagaol, 2013). Representasi matematis erat kaitannya dengan simbol matematis (Leibovich \& Ansari, 2016; Stalnaker \& Zanibbi, 2015). Pada penelitian ini representasi matematis tidak dianalisis seperti pada penelitian lainnya melainkan disajikan melalui permasalahan pada Lembar Kerja Mahasiswa.

Representasi matematis dibagi menjadi tiga jenis yaitu visual, simbolik, dan verbal. Representasi matematis secara visual berkaitan dengan gambar, tabel, diagram, atau grafik. Representasi matematis secara simbolik meliputi pernyataan matematis atau simbol aljabar. Representasi matematis secara verbal berkaitan dengan deskripsi penjelasan solusi matematis (Astuti, 2017). Analisis representasi matematis dapat memberikan bukti terhadap kemampuan matematis mahasiswa, khususnya untuk mendeteksi kesulitan dalam belajar matematika (Jitendra dkk, 2016).

Berdasarkan pengamatan hasil kerja mahasiswa, ditemukan bahwa kemampuan representasi matematis mahasiswa, khususnya pada Program Studi Teknik Sipil masih perlu diperbaiki dan ditingkatkan. Hal ini tampak berdasarkan kesalahan penulisan simbol yang dilakukan mahasiswa yang ditunjukkan dengan tanda lingkaran pada Gambar 1. Mahasiswa kurang tepat dalam menuliskan simbol dalam menyelesaikan masalah.

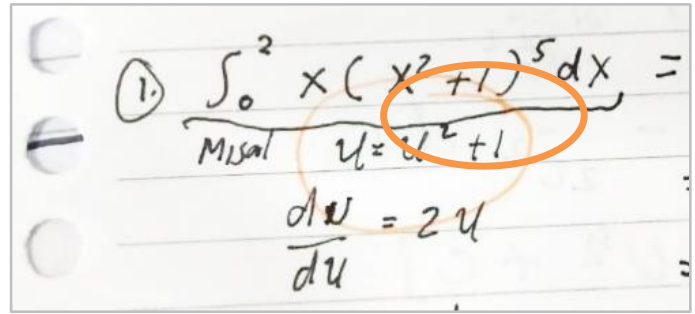

Gambar 1. Contoh kesalahan representasi dalam menyimbolkan

Berdasarkan temuan pada perkuliahan Kalkulus, dirancang perbaikan terkait representasi simbolik maupun verbal mahasiswa Teknik Sipil dengan mengembangkan lembar kegiatan mahasiswa berciri representasi matematis. Pengembangan lembar kegiatan berciri representasi matematis perlu dilakukan untuk melatih mahasiswa memaknai simbol khususnya dalam matematika dan secara umum pada matakuliah lainnya. Kewaspadan terhadap simbol matematika dapat membantu mahasiswa memahami dan menyelesaikan permasalahan yang diberikan dengan tepat dan benar
Penggunaan lembar kegiatan dalam pembelajaran dapat meningkatkan minat belajar mahasiswa (Saregar, 2016). Lembar kegiatan mahasiswa dapat digunakan secara mandiri maupun melalui diskusi di kelas (Diyarko \& Waluya, 2016). Lembar kegiatan yang dibuat dengan tepat dan sistematis dapat membantu mahasiswa belajar lebih baik dalam kegiatan belajar kelompok maupun belajar individu (Fannie \& Rohati, 2014).

Fungsi lembar kegiatan diantaranya adalah memaksimalkan peran mahasiswa dalam pembelajaran, mempermudah mahasiswa memahami materi yang diberikan dan mempermudah kegiatan pelaksanaan 
pembelajaran. Penelitian sebelumnya menyimpulkan bahwa penggunaan Lembar Kegiatan Mahasiswa berbantuan Software Geogebra dapat meningkatkan kemampuan spasial pada mata kuliah Kalkulus (Tonra \& Salim, 2018). Penelitian lain juga menyimpulkan bahwa penggunaan Lembar Aktivitas Mahasiswa berbasis teori APOS dapat meningkatkan kemampuan pemahaman konsep matematika (Ningsih, 2016), dimana Lembar Aktivitas Mahasiswa bercirikan pembentukan mental yang meliputi Action, Processes, Object, dan Schemas (APOS).

Berbagai hasil penelitian yang telah dilakukan menunjukkan manfaat penggunaan Lembar Kegiatan Mahasiswa dalam meningkatkan hasil belajar dan membantu kegiatan pembelajaran. Oleh karena itu, berdasarkan masalah kurangnya kemampuan representasi matematis mahasiswa pada perkuliahan Kalkulus, dipilih alternatif solusi yaitu pengembangan Lembar Kegiatan Kalkulus (LKK) yang dapat memfasilitasi kemampuan representasi matematis mahasiswa. Tujuan penelitian ini adalah mengembangkan Lembar Kegiatan Kalkulus yang valid, praktis dan efektif.

\section{METODE PENELITIAN}

Penelitian ini merupakan research and development yang menggunakan 3 langkah penelitian pengembangan, yaitu penelitian pendahuluan, pembuatan prototipe, dan asesmen. Penelitian pendahuluan dilakukan pada awal penelitian, yang meliputi kegiatan analisis karakteristik mahasiswa, pembelajaran kalkulus, serta ketersediaan bahan ajar. Kegiatan berikutnya adalah pembuatan prototipe, yaitu memuat kegiatan merancang dan membuat LKK, RPP, dan instrumen penelitian serta melakukan penilaian formatif. Instrumen penelitian yang dikembangkan meliputi lembar observasi pembelajaran menggunakan LKK, angket respon mahasiswa terhadap pembelajaran maupun LKK dalam bentuk online (Google Form), serta lembar tes. Angket respon mahasiswa memuat pernyataanpernyataan mengenai tanggapan mahasiswa terhadap pembelajaran dan LKK. Pernyataan-pernyataan terkait respon terhadap pembelajaran meliputi tanggung jawab belajar mahasiswa, kejelasan materi pendahuluan dari dosen, keterbantuan memahami materi pada kegiatan diskusi kelompok dan tanggung jawab memahami materi untuk menyelesaikan soal refleksi. Pernyataan-pernyataan terkait respon terhadap LKK terdiri dari kebermanfaatan LKK untuk membantu mahasiswa memahami dan mewaspadai simbol matematika, kebermanfaat LKK untuk menyadarkan setiap simbol bermakna, dan keberlanjutan penggunaan LKK pada materi selanjutnya. Sedangkan lembar tes berupa soal essay yang terdiri dari 2 soal untuk setiap sub bab.

Kegiatan terakhir adalah asesmen, yang meliputi uji kepraktisan dan keefektivan LKK. LKK dikatakan praktis jika hasil observasi pembelajaran menunjukkan bahwa keterlaksanaan pembelajaran berjalan dengan baik dan mahasiswa memberikan respon positif. LKK dikatakan efektif jika hasil tes kemampuan representasi lebih dari $70 \%$ dari jumlah mahasiswa dalam satu kelas mendapatkan nilai tidak kurang dari 75 . Subjek dalam penelitian ini adalah 38 mahasiswa Teknik Sipil yang menempuh mata kuliah Kalkulus. 
DOI: https://doi.org/10.24127/ajpm.v8i3.2259

Data hasil validasi LKK, RPP, dan instrumen dianalisis dengan cara menentukan rata-rata nilai dari validator, kemudian hasilnya dikategorikan kevalidannya seperti pada Tabel 1. Hasil observasi pembelajaran menggunakan LKK dianalisis dengan cara menentukan rata-rata nilai dari observer, kemudian hasilnya dikategorikan dengan tingkatan seperti pada Tabel 2.

Tabel 1. Kriteria kevalidan

\begin{tabular}{cc}
\hline Nilai Kevalidan & Tingkat Kevalidan \\
\hline $0 \leq \bar{V} \leq 1$ & Tidak Valid \\
$1<\bar{V}<2$ & Cukup Valid \\
$2<\bar{V} \leq 3$ & Valid \\
\hline
\end{tabular}

Tabel 2. Tingkat hasil observasi pembelajaran menggunakan LKK

\begin{tabular}{ll}
\hline Rata-rata & \multicolumn{1}{c}{ Tingkat Hasil Observasi } \\
\hline $0 \leq \bar{O} \leq 1$ & $\begin{array}{l}\text { Rendah, perlu dilakukan revisi total terhadap } \\
\text { pelaksanaan pembelajaran menggunakan LKK }\end{array}$ \\
$1<\bar{O}<2$ & $\begin{array}{l}\text { Cukup, perlu revisi sebagian terhadap pelaksanaan } \\
\text { pembelajaran menggunakan LKK }\end{array}$ \\
$2<\bar{O} \leq 3$ & Baik, tidak perlu revisi \\
\hline
\end{tabular}

Hasil angket respon mahasiswa menggambarkan respon mahasiswa terhadap LKK serta kegiatan pembelajaran menggunakan LKK.
Kriteria kepraktisan rata-rata nilai dari angket respon mahasiswa disajikan pada Tabel 3.

Tabel 3. Kriteria kepraktisan dari angket respon mahasiswa

\begin{tabular}{ll}
\hline Rata-rata & \multicolumn{1}{c}{ Kategori } \\
\hline $0 \leq \bar{A}<1$ & Respon Negatif, perlu dilakukan uji coba ulang \\
$1 \leq \bar{A} \leq 2$ & Respon Positif, tidak perlu dilakukan uji coba ulang \\
\hline
\end{tabular}

LKK untuk mahasiswa Teknik Sipil yang dikembangkan dikatakan efektif apabila lebih dari $70 \%$ mahasiswa dari total jumlah mahasiswa dalam satu kelas dapat merepresentasikan matematis dengan kategori minimal baik.

\section{HASIL PENELITIAN DAN PEMBAHASAN}

LKK yang dikembangkan memuat materi Fungsi Dua Variabel atau Lebih, Turunan Parsial, dan Turunan Parsial Tingkat Tinggi. Masing-masing LKK memuat identitas mahasiswa, tujuan pembelajaran, dan bagian inti. Bagian inti memuat: (1) pertanyaan-pertanyaan yang membimbing untuk menuliskan rangkuman berdasarkan referensi yang telah dibaca mahasiswa, (2) permasalahan berkaitan dengan representasi simbolik yang didiskusikan secara berkelompok, (3) soal refleksi untuk menguji kompetensi mahasiwa. Tampilan LKK disajikan pada Gambar 2. Tujuan pembelajaran pada ketiga LKK ditunjukkan pada Tabel 4. 
DOI: https://doi.org/10.24127/ajpm.v8i3.2259

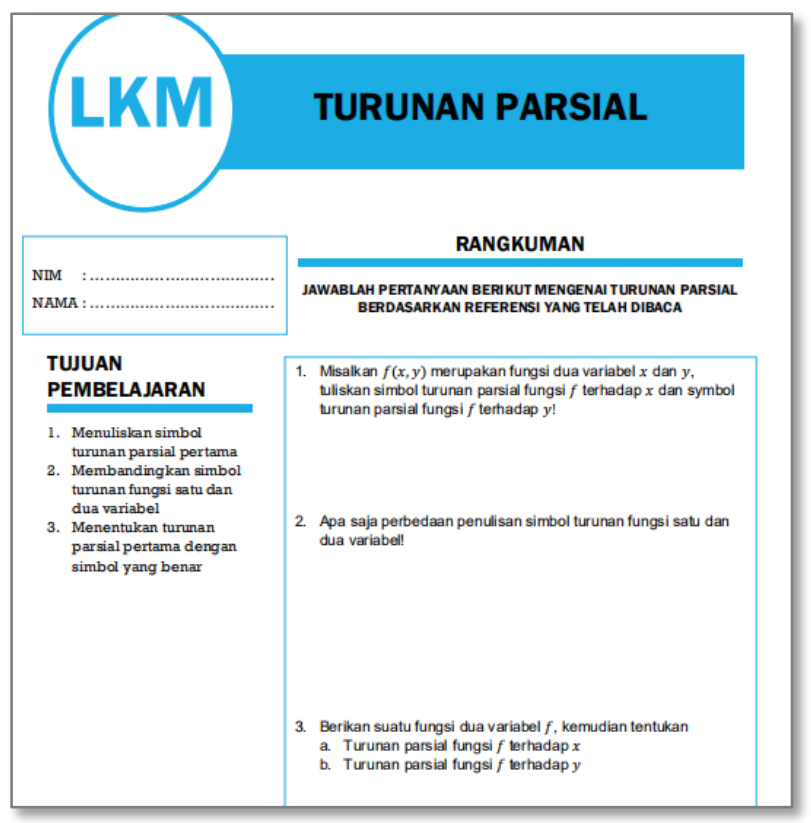

Gambar 2. Tampilan halaman pertama materi turunan parsial pada LKK

Tabel 4. Tujuan pembelajaran pada lembar kegiatan kalkulus

Materi

Fungsi Dua Variabel atau Lebih

Turunan Parsial

Turunan Parsial Tingkat Tinggi

\section{Tujuan Pembelajaran}

1. Membedakan fungsi dua variabel atau lebih dengan fungsi satu variabel.

2. Menentukan variabel bebas dan terikat fungsi dua variabel menggunakan simbol yang benar

3. Menentukan nilai fungsi jika diketahui nilai varabelnya dengan penulisan simbol yang benar.

4. Menentukan daerah asli domain menggunakan simbol yang benar

1. Menuliskan simbol turunan parsial pertama

2. Membandingkan simbol turunan fungsi satu dan dua variabel

3. Menentukan turunan parsial pertama dengan simbol yang benar

1. Menuliskan simbol turunan parsial tingkat tinggi

2. Membandingkan simbol turunan fungsi tingkat satu dan turunan tingkat tinggi fungsi dua variabel

3. Menentukan turunan tingkat tinggi menggunakan simbol yang benar
Rencana Pelaksanaan Pembelajaran yang disusun terdiri dari tiga pertemuan. Pendekatan pembelajaran menggunakan konstruktivis, dengan strategi kooperatif, dan metode pembelajaran melalui pemberian tugas, diskusi, dan tanya jawab. Langkah-langkah pembelajaran memuat kegiatan pendahuluan, inti, dan penutup. Pada pendahuluan mahasiwa disiapkan untuk duduk sesuai kelompok, serta menerima LKK. Pada kegiatan inti, diawali 
dengan menulis rangkuman melalui menjawab pertanyaan-pertanyaan terbimbing pada LKK. Selajutnya, membahas penyelesaian soal rangkuman melalui diskusi klasikal dengan bimbingan dosen. Kegiatan berikutnya adalah menyelesaikan masalah pada LKK melalui diskusi kelompok, dan membahas penyelesaiannya melalui diskusi klasikal dengan bimbingan dosen. Kegiatan penutup diakhiri dengan menyelesaikan Soal Refleksi serta dosen mengingatkan mahasiswa untuk membaca materi berikutnya di rumah.

Instrumen penelitian yang dikembangkan terdiri dari lembar validasi, lembar observasi, lembar angket respon mahasiswa, dan lembar tes. Lembar validasi yang dikembangkan terdiri dari lembar validasi LKK, RPP, lembar observasi, lembar angket respon mahasiswa. Aspek yang dinilai pada tes termuat dalam lembar validasi LKK. Aspek yang dinilai pada masing-masing lembar validasi dijelaskan pada Tabel 5.

Tabel 5. Aspek penilaian pada lembar validasi

\begin{tabular}{ll}
\hline \multicolumn{1}{c}{ Lembar Validasi } & \multicolumn{1}{c}{ Aspek yang Dinilai } \\
\hline LKK & Sistematika; Isi/Konten; Bahasa, Tulisan, dan Tampilan; \\
& Manfaat LKK \\
RPP & Isi/Konten; Bahasa, Tulisan, dan Tampilan; Manfaat \\
& RPP \\
Lembar Observasi & Isi/Konten; Bahasa, Tulisan, dan Tampilan; Manfaat \\
& Lembar Observasi \\
Lembar Angket Respon & Isi/Konten; Bahasa, Tulisan, dan Tampilan; Manfaat \\
Mahasiswa & Lembar Angket Respon \\
\hline
\end{tabular}

Lembar observasi disusun untuk mengetahui proses pelaksanaan pembelajaran menggunakan LKK. Aspek yang diperhatikan meliputi:

1) Mengawali kegiatan belajar dengan berdoa bersama.

2) Mahasiswa menerima LKK dan memperhatikan penjelasan dosen tentang tujuan pembelajaran yang akan dicapai.

3) Mahasiswa duduk sesuai kelompok yang telah ditentukan.

4) Menuliskan rangkuman melalui penyelesaian soal pada LKK.

5) Membahas penyelesaian soal rangkuman melalui diskusi klasikal.

6) Menyelesaikan soal LKK melalui diskusi kelompok.

7) Membahas penyelesaian soal LKK melalui diskusi klasikal.
8) Menyelesaikan soal pada Exersice sebagai evaluasi representasi matematis.

9) Mengumpulkan hasil LKK.

10) Dosen mengingatkan mahasiswa untuk membaca materi Turunan Parsial di rumah untuk perkuliahan selanjutnya.

Lembar angket respon mahasiswa dibuat dalam bentuk online melalui google form. Angket respon mahasiswa ini dapat diakses melalui link https://forms.gle/niw9pZ9CgHBvs5q16. Mahasiswa memberikan respon dengan memilih salah satu dari empat kondisi yang diberikan dan atau menuliskan sendiri alasan lain jika tidak ada pada pilihan yang diberikan. Mahasiswa diminta mengisi angket respon setelah kegiatan tes pertemuan ketiga dilaksanakan. Pengisian angket respon 
DOI: https://doi.org/10.24127/ajpm.v8i3.2259

mahasiswa dilakukan melalui smartphone masing-masing mahasiswa.

Lembar tes yang disusun memuat soal-soal bercirikan representasi matematis simbolik dan verbal. Lembar tes ini termuat pada setiap akhir LKK. Terdapat tiga lembar tes dengan materi Fungsi Dua Variabel atau Lebih, Turunan Parsial, dan Turunan Parsial Tingkat Tinggi. Tes pertama memuat indikator yaitu memberikan contoh fungsi dua variabel atau lebih dengan simbol yang benar, menentukan daerah asal alami dengan simbolyang benar, dan menentukan nilai fungsi dua variabel atau lebih untuk variabel bebas tertentu dengan simbol yang benar. Tes kedua memuat indikator antara lain menyelidiki kesamaan turunan parsial pada variabel yang berbeda dengan simbol yang benar, dan menyelidiki kesamaan nilai fungsi dari turunan parsial fungsi dua variabel atau lebih pada variabel yang berbeda dengan simbol yang benar. Tes ketiga memiliki indikator yang terdiri dari menentukan turunan parsial tingkat dua dengan simbol yang benar, dan menyelidiki kesamaan nilai fungsi dari turunan parsial tingkat dua fungsi dua variabel atau lebih pada variabel yang berbeda dengan simbol yang benar.

Kevalidan LKK, RPP, dan Instrumen LKK, RPP, dan instrumen penelitian divalidasi pada dosen Pendidikan Matematika. Hasil validasi disajikan pada Tabel 6 .

Tabel 6. Hasil validasi.

\begin{tabular}{lcc}
\hline \multicolumn{1}{c}{ Validasi } & Rata-Rata Skor & Kategori \\
\hline LKK & 2,60 & Valid \\
RPP & 2,70 & Valid \\
Lembar Observasi & 2,56 & Valid \\
Lembar Angket & 2,64 & Valid \\
Respon & & \\
\hline
\end{tabular}

Hasil validasi LKK masuk pada kategori valid. Skor maksimal yang diberikan pada aspek sistematika meliputi tujuan pembelajaran dinyatakan jelas pada LKK, terdapat soal-soal yang membimbing mahasiswa untuk menuliskan rangkuman, serta terdapat kegiatan menyelesaikan soalsoal terkait representasi matematis pada materi Kalkulus. Skor maksimal yang diberikan pada aspek bahasa, tulisan, dan tampilan meliputi bahasa yang digunakan jelas sehingga tidak menimbulkan penafsiran ganda, serta tampilan warna, ukuran huruf, dan gambar yang digunakan jelas terbaca sehingga mudah dipahami mahasiswa. Manfaat LKK juga memperoleh skor maksimal yang terdiri dari memfasilitasi dosen dan mahasiswa dalam kegiatan pembelajaran di kelas, serta mengarahkan mahasiswa untuk meningkatkan representasi matematis.

Hasil validasi RPP masuk kategori valid tanpa revisi. Skor maksimal diberikan pada isi yang terdiri dari papaian pembelajaran dan kemampuan akhir yang diharapkan sesuai dengan silabus matakuliah Kalukulus, indikator dirumuskan secara jelas dan spesifik sehingga dapat diukur, kegiatan menyelesaikan latihan soal dinyatakan dengan jelas, serta kegiatan mahasiswa dalam menyelesaikan latihan soal secara berkelompok dinyatakan dengan jelas. Skor maksimal juga diberikan pada aspek bahasa, tulisan, tampilan, dan manfaat yang meliputi menggunakan 
bahasa dan kalimat yang mudah dipahami dosen model, menggunakan bahasa yang jelas sehingga tidak menimbulkan penafsiran ganda, serta dapat digunakan dosen sebagai panduan untuk melaksanakan pembelajaran dengan menggunakan LKK untuk meningkatkan representasi matematis.

Hasil validasi instrumen penelitian yaitu lembar observasi, angket, dan tes masing-masing masuk kategori valid. Skor maksimal yang mendukung kevalidan lembar observasi diberikan pada petunjuk pengisian jelas dan mudah dipahami, serta pernyataanpernyataan pada lembar observasi mahasiswa mencakup semua kegiatan yang harus dilakukan mahasiswa. Hasil kevalidan lembar angket ini didukung dengan respon mahasiswa yang akan digali dinyatakan dengan jelas, serta menggunakan kalimat yang mudah dipahami mahasiswa.

\section{Kepraktisan LKK}

Hasil observasi aktivitas

mahasiswa memiliki rata-rata 2,60

dengan kategori baik. Hal ini didukung

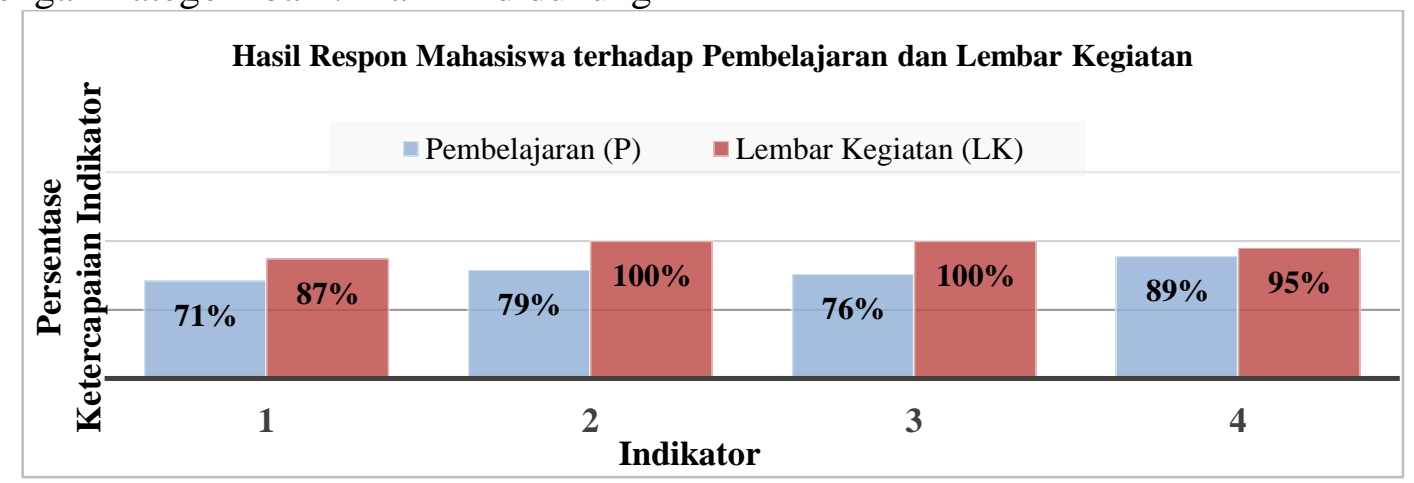

Gambar 3. Hasil respon mahasiswa terhadap pembelajaran dan LKK

Keterangan Indikator Pernyataan Respon terhadap Pembelajaran (P):

1: Mahasiswa memiliki tanggung jawab belajar sebelum kelas dimulai

2: Pendahuluan dari dosen membantu siswa untuk memahami materi

3: Kegiatan diskusi kelompok membantu siswa untuk memahami materi

4: Mahasiswa memiliki tanggung jawab untuk menyelesaikan soal refleksi 
DOI: https://doi.org/10.24127/ajpm.v8i3.2259

Keterangan Indikator Pernyataan Respon terhadap Lembar Kegiatan (LK):

1: Lembar Kegiatan membantu mahasiswa memahami simbol matematika

2: Lembar Kegaiatan memberikan kesadaran simbol matematika

3: Setiap simbol matematika memiliki makna

4: Lembar Kegiatan serupa dapat diterapkan pada materi/perkuliahan lainnya

Berdasarkan hasil angket respon mahasiswa terhadap pembelajaran diperoleh $71 \%$ mahasiswa memiliki tanggung jawab belajar sebelum kelas dimulai, $79 \%$ mahasiswa memberikan pendapat bahwa pendahuluan dari dosen membantu siswa untuk memahami materi, $76 \%$ mahasiswa berpendapat kegiatan diskusi kelompok membantu siswa untuk memahami materi, dan 89\% mahasiswa memiliki tanggung jawab untuk menyelesaikan soal refleksi. Berdasarkan hasil angket respon mahasiswa terhadap LKK diperoleh bahwa $87 \%$ mahasiswa setuju bahwa LKK membantu mahasiswa memahami simbol matematika, $100 \%$ mahasiswa setuju bahwa LKK memberikan kesadaran simbol matematika, $100 \%$ mahasiswa setuju bahwa setiap simbol matematika memiliki makna, dan 95\% setuju bahwa LKK serupa dapat diterapkan pada materi/perkuliahan lainnya. Berdasarkan analisis hasil rata-rata diperoleh 1,78 dari 2,00. Hasil ini masuk pada kategori respon positif. Berdasarkan hasil observasi pembelajaran menggunakan LKK yang baik dan respon mahasiswa yang positif, disimpulkan bahwa LKK ini praktis.

\section{Keefektivan LKK}

Berdasarkan hasil tes pada masingmasing pertemuan diperoleh data representasi matematis yang disajikan pada Gambar 4.

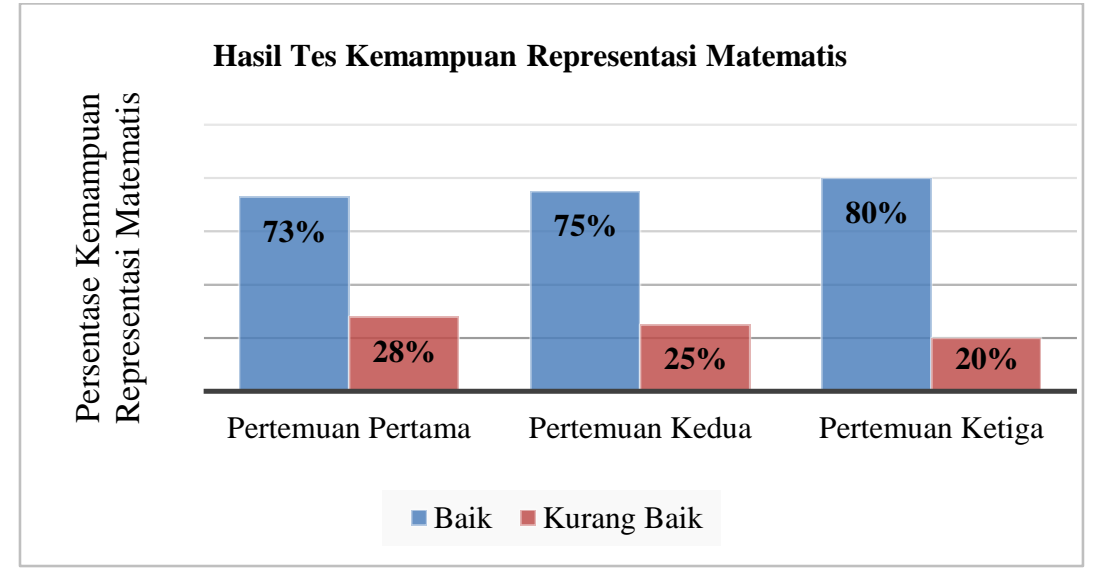

Gambar 4. Hasil Representasi Matematis

Diagram batang pada Gambar 4 menjelaskan bahwa tes pada pertemuan pertama terdapat $73 \%$ mahasiswa yang dapat merepresentasikan simbol dan verbal dengan baik. Hasil tes pada pertemuan kedua diperoleh data bahwa $75 \%$ mahasiswa yang dapat merepresentasikan simbol dan verbal dengan baik. Hasil tes pada pertemuan ketiga didapatkan $80 \%$ mahasiswa dapat merepresentasikan simbol dan verbal dengan baik. Berdasarkan data tersebut, dapat disimpulkan bahwa LKK dinyatakan efektif.

Terdapat beberapa temuan dalam penelitian ini yang dicatat berdasar kegiatan pembelajaran, pengerjaan LKK dan hasil pengerjaan tes mahasiswa. 
DOI: https://doi.org/10.24127/ajpm.v8i3.2259

Mahasiswa memberikan respon positif terhadap pembelajaran dengan menggunakan lembar kegiatan. Dosen juga merasa terbantu dan lebih mudah melaksanakan rencana kegiatan pembelajaran dengan adanya lembar kegiatan yang digunakan. Kebermanfaatan lembar kegiatan bagi mahasiswa, sebagai peserta didik, dan dosen, sebagai pendidik, sejalan dengan penelitian Zukhrufurrohmah, dkk (2017) dan Ismail, dkk (2017) yang menyimpulkan bahwa lembar kegiatan dapat membantu peserta didik dalam meningkatkan kemampuan matematisnya dan dapat memudahkan kegiatan pembelajaran di kelas.

Hasil pengerjaan tes menunjukkan bahwa mahasiswa dapat mengubah simbol $\frac{\partial f(x, y)}{\partial y}$ menjadi $f_{y}(x, y)$ dengan benar ketika menyelesaikan masalah. Namun sebagian mahasiswa memerlukan waktu lebih banyak untuk mengenali dan memaknai simbol $\frac{\partial^{2} z}{\partial^{2} x}$ dibandingkan dengan simbol $f_{x x}(x, y)$. Berdasar catatan observasi kegiatan pembelajaran, kemampuan mengenal dan memaknai simbol-simbol matematika membantu mahasiswa untuk tidak melakukan kesalahan dalam memahami masalah. Hal ini sejalan dengan hasil penelitian Farhan \& Zulkarnain (2019) yang menemukan bahwa salah satu penyebab kesalahan mahasiswa dalam menyelesaikan soal kalkulus adalah kesalahan dalam memahami soal yang berupa representasi simbol matematika. Penemuan lain terkait pemaknaan simbol adalah mahasiswa dapat membedakan antara simbol fungsi dan nilai fungsi baik secara simbolik maupun verbal.

\section{KESIMPULAN DAN SARAN}

Lembar kegiatan kalkulus yang dikembangkan dinyatakan valid, praktis dan efektif. LKK dinyatakan valid karena hasil validasi menyatakan bahwa $86 \%$ indikator kevalidan LKK terpenuhi. Dengan kata lain skor validitas yang diperoleh adalah 2,60 dari skor maksimal 3,00. LKK yang dikembangkan memenuhi kriteria praktis karena $85 \%$ rencana pembelajaran terlaksana dengan baik yang ditunjukkan dengan hasil observasi keterlaksanaan pembelajaran dengan menggunakan LKK yang memperoleh skor 2,56 dari skor maksimal 3,00. Kepraktisan LKK juga didasarkan pada hasil respon positif yang diberikan mahasiswa terhadap LKK dan pembelajaran dnegan LKK. Kriteria efektif disimpulkan berdasar hasil pengerjaan tes yang diberikan kepada mahasiswa yang menunjukkan lebih dari $70 \%$ mahasiswa dalam satu kelas memiliki kemampuan representasi simbolik dan verbal yang baik.

Temuan pada penelitian ini menunjukkan bahwa mahasiswa awalnya tidak memiliki kepedulian dan kewaspadaan terhadap simbol matematika khususnya simbol turunan fungsi. Hal ini mengakibatkan mahasiswa kesulitan menyelesaikan soal yang diberikan. Temuan peneliitian juga menunjukkan bahwa mahasiswa yang tidak memaknai simbol atau kurang peduli terhadap simbol banyak melakukan kesalahan ketika menuliskan hasil diskusi kelompok pada LKK.

Penelitian ini menunjukkan bahwa pendidik juga harus menyadari penggunaan simbol matematika yang benar. Oleh karena itu, pendidik dapat membimbing peserta didik untuk mengenali simbol matematika. Penelitian selanjutnya diharapkan dapat mendesain pembelajaran melalui 
pengembangan bahan ajar maupun perangkat pembelajaran lainnya untuk meningkatkan representasi matematis.

\section{DAFTAR PUSTAKA}

Astuti, E. P. (2017). Representasi Matematis Mahasiswa Calon Guru dalam Menyelesaikan Masalah Matematika. Beta Jurnal Tadris Matematika, 10(1), 70-82. https://doi.org/10.20414/betajtm.v1 $0 \mathrm{i} 1.100$

Diyarko \& Waluya, S. B. (2016). Kemampuan Literasi Matematika Ditinjau dari Metakognisi dalam Pembelajaran Inkuiri Berbantuan Lembar Kerja Mandiri Mailing Merge. Unnes Journal of Mathematics Education Research, 5(1).

Fannie, R. ., \& Rohati. (2014). Pengembangan Lembar Kerja Siswa (LKS) Berbasis POE (Predict, Observe, Explain) Pada Materi Program Linier. Jurnal Sainmatika, 8(1), 96-109.

Farhan, M., \& Zulkarnain, I. (2019). Analisis Kesalahan Mahasiswa pada Mata Kuliah Kalkulus Peubah Banyak Berdasarkan Newmann's Error Analysis. Jurnal Kajian Pendidikan Matematika, 4(2), 121-134.

Hutagaol, K. (2013). Pembelajaran Kontekstual untuk Meningkatkan Kemampuan Representasi Matematis Siswa Sekolah Menengah Pertama. Infinity Journal, 2(1), 85-99. https://doi.org/10.22460/infinity.v2 i1.27

Ismail, A. D., Jamil, A. F., \& Putri, O. R. U. (2017). Pengembangan Modul Trigonometri Bercirikan
Open-Ended Problem. AdMathEdu : Jurnal Ilmiah Pendidikan Matematika, Ilmu Matematika Dan Matematika Terapan, $\quad 7(1), \quad 1-8$. https://doi.org/10.12928/admathed u.v7i1.7396

Jitendra, A. K. et al. (2016). Is mathematical representation of problems an evidence-based strategy for students with mathematics difficulties? Exceptional Children, 83, 8-25. https://doi.org/10.1177/001440291 5625062

Leibovich, T., \& Ansari, D. (2016). The Symbol-Grounding Problem in Numerical Cognition: A Review of Theory, Evidence, and Outstanding Questions. Canadian Journal of Experimental Psychology, 70(1), 12-23.

https://doi.org/10.1037/cep000007

0

Lestari, K. E., \& Yudhanegara, M. R. (2017). Analisis Kemampuan Representasi Matematis Mahasiswa pada Mata Kuliah Geometri Transformasi Berdasarkan Latar Belakang Pendidikan Menengah. Jurnal Matematika Integratif, 13(1), 2833.

https://doi.org/10.24198/jmi.v13.n 1.11410.29-34

Ningsih, Y. L. (2016). Kemampuan Pemahaman Konsep Matematika Mahasiswa Melalui Penerapan Lembar Aktivitas Mahasiswa (LAM) Berbasis Teori APOS Pada Materi Turunan. Edumatica, 6(1). https://doi.org/10.1063/1.4944618

Purnomo, E.A. \& Faturohman, A. (2014). Pengembangan Perangkat 
DOI: https://doi.org/10.24127/ajpm.v8i3.2259

Pembelajaran dengan Model Ideal Problem Solving Berbasis Maple Matakuliah Kalkulus II. Semarang: Universitas Muhamamdiyah Semarang.

Sabirin, M. (2014). Representasi dalam Pembelajaran Matematika. Jurnal Pendidikan Matematika, 1(2), 3344.

https://doi.org/10.18592/jpm.v1i2. 49

Saregar, A. (2016). Pembelajaran Pengantar Fisika Kuantum dengan Memanfaatkan Media Phet Simulation dan LKM Melalui Pendekatan Saintifik: Dampak pada Minat dan Penguasaan Konsep Mahasiswa. Jurnal Ilmiah Pendidikan Fisika Al-Biruni, 5(1), 53-60.

https://doi.org/10.24042/jpifalbirun i.v5i1.105

Stalnaker, D., \& Zanibbi, R. (2015). Math expression retrieval using an inverted index over symbol pairs. Document Recognition and Retrieval XXII. https://doi.org/10.1117/12.2074084

Tonra, W. S., \& Salim, A. (2018). Pengembangan Lembar Kegiatan Mahasiswa (LKM) Kalkulus Berbantuan Software Geogebra untuk Meningkatkan Kemampuan Spasial. SAINTIFIK, 4(2), 156166.

https://doi.org/10.31605/saintifik.v $4 \mathrm{i} 2.181$
Zukhrufurrohmah, Sa'dijah, C., \& Muksar, M. (2017). Pengembangan Bahan Ajar Bercirikan Penemuan Terbimbing dan Berbantuan Aplikasi pada Materi untuk Kelas X SMK. Jurnal Kajian Pembelajaran Matematika, 1(2), 137-143. 